\title{
GALAXY(Glycoanalysis by the Three Axes of MS and Chromatography): a Web Application that Assists Structural Analyses of $N$-Glycans
}

\author{
糖鎖構造解析を支援するためのウェブアプリケーション \\ “GALAXY” (Glycoanalysis by the Three Axes of MS and Chromatography)
}

\author{
Takahashi, Noriko ; and Kato, Koichi \\ Graduate School of Pharmaceutical Sciences Nagoya City University, Tanabe-dori 3-1, Mizuho-ku, Nagoya 467-8603, Japan \\ FAX : +81-52-836-3450, E-mail: ntakahas@ phar.nagoya-cu.ac.jap
}

Key Words: GALAXY, web application, $N$-Glycans, 2-D/3-D Map

\begin{abstract}
Since the 2-D/3-D HPLC mapping technique was proposed for structural analyses of $\mathrm{N}$-glycans, approximately 500 different structures have been elucidated. Based on the accumulated data, we developed a web application, GALAXY (Glycoanalysis by the three axes of MS and chromatography), to utilize the 2-D/3-D maps more effectively. This application will facilitate search of candidate structures satisfying 2-D/3-D HPLC and/or mass spectrometric data and enable us to predict coordinates of putative PA-glycans and to trace the effects of glycosidase treatments in a graphical manner.
\end{abstract}

要 約

アスパラギン残基に結合している糖鎖 ( $\mathrm{N}$ 型糖鎖) の構造解 析法として“2-D/3-D糖鎖マッピング法”を私達が提唱 (Anal. Biochem., 1988 年, 1995 年) して以来、約 500 種に及ぶ糖鎖構造 がこの方法により明らかになりました。この蓄積されたデー夕 を基にして 2-D/3-D 糖鎖マッピング法をより効果的に利用する ために私達はウェブアプリケーション“G A L A X Y ”

(Glycoanalysis by the three axes of MS and chromatography)を開発 しました。

このアプリケーションは、2-D/3-D 糖鎖マッピング法あるい は質量分析によって得られたデー夕にあてはまる構造の候補を 蓄積されたデー夕から探し出すのを容易にします。また推定し たPA 糖鎖のマップ上の座標值を予想したり、PA 糖鎖にグリコ シダーゼ処理を施した場合におけるマップ上の座標値の移動を グラフィカルに追跡することも可能です。

\section{A. 2-D/3-D HPLC Mapping Technique}

\section{A-1. Introduction}

We briefly explain the 2-D/3-D mapping method which has been developed for the structural determination of asparagine-linked oligosaccharides (N-glycans) in glycoproteins.

In this method, $\mathrm{N}$-glycans are released from the protein portion and the reducing ends are fluorescent labeled with 2aminopyridine. These pyridylamino (PA)-glycans are separated by HPLC using three different columns sequentially; and from the elution positions on three HPLC columns, the structures of PA-glycans are simultaneously estimated.

The structure of a sample PA-glycan can be estimated by comparing its elution position on the map with the positions of the known reference $\mathrm{N}$-glycans plotted on the 2-D map. The sample PA-glycan and one of the candidate reference PA-glycans are co-injected into two HPLC columns to confirm a single peak. Furthermore, the sample PA-glycans are digested with several glycosidases, then the changes of the elution positions are again compared with those of the reference $\mathrm{N}$-glycans.

This method is useful not only as an analytical procedure for $\mathrm{N}$-glycan structures, but also as a means of isolating large scale samples for NMR spectroscopy or MS spectrometry.
A. 糖鎖マップとは

A-1. はじめに

糖タンパク質のアスパラギン残基に結合している糖鎖 $(\mathrm{N}$ 型 糖鎖)の構造解析法として私達が開発してきた“2-D/3-D糖鎖マッ ピング法”について簡単に解説します。

この分析法は、まず糖鎖を酵素的にタンパク質から切り離 し、糖鎖の還元末端を 2-アミノピリジンで蛍光ラベルします。

この PA 糖鎖を、 3 種類の分離モードの HPLC カラムを用いて 連続的に分離すると同時に、その溶出位置から構造を推定する という仕組みです。

構造の同定の基本は、試料 PA 糖鎖のカラムからの溶出位 置を、マップ上の既知の標準 PA 糖鎖の位置と比較することで すが、必要に応じて標準糖鎖との共打ち、また各種グリコシ ダーゼ消化前後のカラムからの溶出位置の変化をマップ上でグ ラフィカルに追跡することにより構造を解析します。

この手法は、中性糖鎖とシアリル糖鎖が全く同じカラム、 同じ溶出条件で分離同定できる点が便利で優れており、また単 に糖鎖の分離精製法としての観点だけから見ても良い方法なの で、NMR や質量分析のための糖鎖の単離精製という目的に使 える利点があります。

この分析法ではタンパク質が $1 \mathrm{mg}$ あれば大抵の場合は糖鎖 分析が可能です。HPLCカラムでは、ピコモル $(\mathrm{pmol})$ 及至フエ ムトモル (fmol) の PA 糖鎖の検出ができます。

構造を同定した糖鎖 1 つ 1 つには数字と必要に応じてアル ファベットを組み合わせたコード番号 (例えば $110.4 \mathrm{~F} や 3 \mathrm{~A} 1$ 300.8)をつけて体系的に分類しています。

今回公開した最新のデータベースは、これまでに解析蓄積 した 500 種類に及ぶ PA 糖鎖の構造式、ODS カラムおよびアミ 
Approximately $1 \mathrm{mg}$ of glycoprotein is used in this method. PA-oligosaccharides (pico moles or femto moles) are used for one run of HPLC analysis.

The identified $\mathrm{N}$-glycan structures are coded by code numbers with alphaneumeric characters (Code Number, e.g. $110.4 \mathrm{~F}$, or $3 \mathrm{~A} 1-300.8$, etc.)

The new Web application contains data on approximately 500 different PA-glycans: It includes the structures, HPLC elution positions expressed in glucose units (GU) on ODS and amide-silica columns, relative molecular mass, code numbers, sources of samples, and references.

\section{A-2. Glucose Unit (GU)}

GU expresses essentially the elution time of a sample from an HPLC column. The elution time expressed in real time or volume can vary depending on the individual column, its age, or the batches of buffers used. The introduction of the GU is meant to reduce such variations.

Let us explain how to express elution time as a GU, using Fig.1. Both the ODS and the amide columns are first calibrated respectively with a commercial PA-derivatized isomaltooligosaccharide mixture. Numbers $(4,5,6$, etc.) indicate the degree of glucose polymerization. Sample PA-glycan is then applied to the column. Red peaks show the elution positions of the samples. The elution time of the sample compared with those of the glucose oligomers and the GU are estimated. The next step is plotting the GU values; 14.7 on the $\mathrm{X}$-axis and 6.7 on the Y-axis are plotted on the 2-D map as coordinates (red dot) and compared with the coordinates of known reference $\mathrm{N}$-glycans
ドカラムにおける溶出位置、マススペクトロメトリーで得られ る PA 糖鎖の分子量、コード番号、試料糖鎖の起源、参考文献 が含まれています。

\section{A-2. グルコース単位 $(G U)$}

グルコース単位 $(\mathrm{GU})$ とは、本質的には試料の溶出時間を 表しています。個々のカラムによる差、経時変化、用時に調製 する溶媒の微妙な違い等から生ずる試料の溶出時間の差異に普 遍性を与えるために、試料の溶出時間をグルコースの重合度に 換算して GU として表現しています。

どのようにして試料の溶出時間を GU で表すか説明します (図 1)。

ODS カラムとアミドカラムにそれぞれ市販の標準 PA 化グ ルコース重合体混合物を当日試料を分析する前に流すことに よって試料のカラムからの溶出位置が補正規格化されます。 4 , 5，6等の数字は各グルコースの重合度を示します。赤色ピーク は試料糖鎖の溶出位置を示します。

$\mathrm{PA}$ 糖鎖試料のピークの溶出時間をグルコース重合体の溶出 時間と比較して GU に換算し、2-D マップ上の值とします。次 にこの例では試料糖鎖の X 軸上の座標 14.7 と Y 軸上の座標 6.7 を 1 組の座標 (赤い点) としてマップに目盛り、既知のデータ(
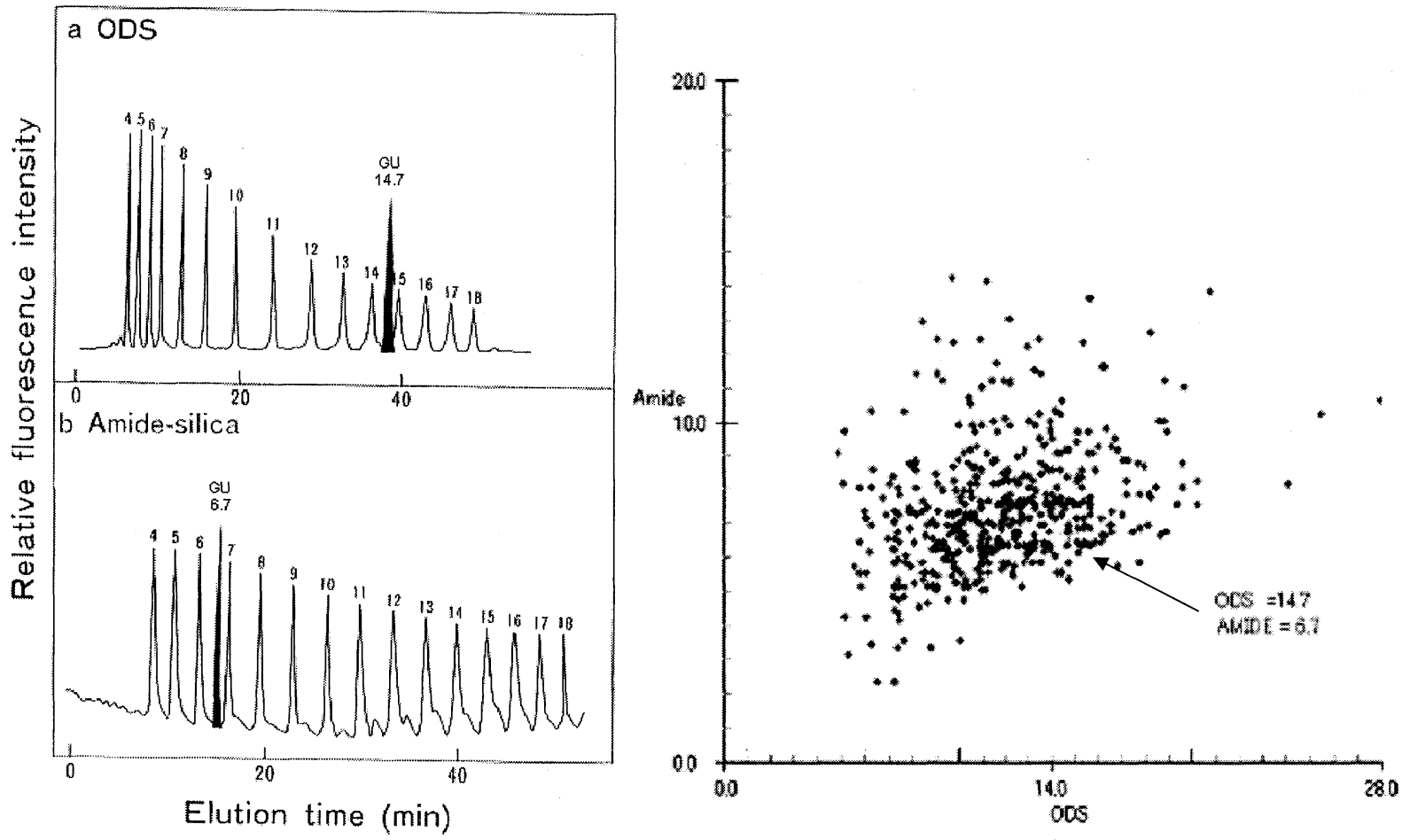

Fig.1. Measurements of Glucose Unit(GU) values. 
(blue dots) plotted on the 2-D map.

Since we first published 113 different N-glycan structures and their GU values on the 2-D map in 1988, in Analytical Biochemistry we have not had any need to revise them. However, if you use columns different from ours (Shim-pack HRCODS column and Amide- 80 column), it may be difficult to obtain the same GU values.

\section{A-3. The Make-Up of the 2-D/3-D Map}

(1) The PA-glycan mixture is separated on a DEAE (diethylaminoethyl) column according to its sialic acid content into neutral, mono-sialyl, di-sialyl, etc. This is the first step in the 3-D mapping method.

(2) Next, using the two different types of HPLC columns (an ODS and an amide column), sample PA-glycans fractionated on the DEAE column are further purified and their structures are simultaneously estimated. The procedure is called the 2-D mapping method. The elution time on the ODS column is expressed as a GU to be plotted on the X-axis. The GU value on the ODS column depends on the fine structure of each. The 2-D mapping method is completely included in the 3-D mapping method.

Even oligosaccharides of the same molecular size can be separated on the X-axis. Separation profiles are very sharp.

(3) Each sample PA-glycan separated on the ODS column is applied to the amide column, and the elution time is expressed as a GU to be plotted on the Y-axis. The GU value on the amide column (Y-axis) depends roughly on the molecular mass of each oligosaccharide.
青い点) と比較しています。

最初に Analytical Biochemistry 誌に 113 個の糖鎖構造とそ の 2-D マップ上の GU が発表されたのは 1988 年ですが、その 時の值は今でも全く訂正の必要がありません。ただ、カラムは 私達が使用しているもの (Shim-pack HRC-ODS カラムおよび Amide-80 カラム) と同じでないと GU 值が合わないようです。

A-3. 2-D / 3-D 糖鎖マップの作り方

2-D マップ法と 3-D マップ法の関係：2-D マップ法は 3-D マップ法に完全に含まれています。

(1) PA 糖鎖の混合物を DEAE (diethylaminoethyl) カラムなと の陰イオン交換カラムでシアル酸残基の数によって中性糖鎖、 モノシアリル糖鎖、ジシアリル糖鎖のように分離します。これ が3-Dマップ法の第 1 段階です。

(2) 次に、分離の原理の異なる 2 種類のカラムを用いた HPLCで、先にチャージによって分かれた中性糖鎖、モノシア リル糖鎖、ジシアリル糖鎖などの画分をそれぞれ分離精製し、 それと同時に各糖鎖の溶出位置から、その構造を推定するのが 2-D マップ法です。2-D マップ法で最初に使う ODS カラムは、 たとえ同じ分子サイズの異性体でも残基の結合位置の違いなど 微細な違いを見分け分離することができ、分離は実にシャープ です。

(3) ODS カラムから溶出した各分画を、アミドカラムで分離 精製します。この第3のカラムは主として糖鎖の分子サイズに よって分離することができます。
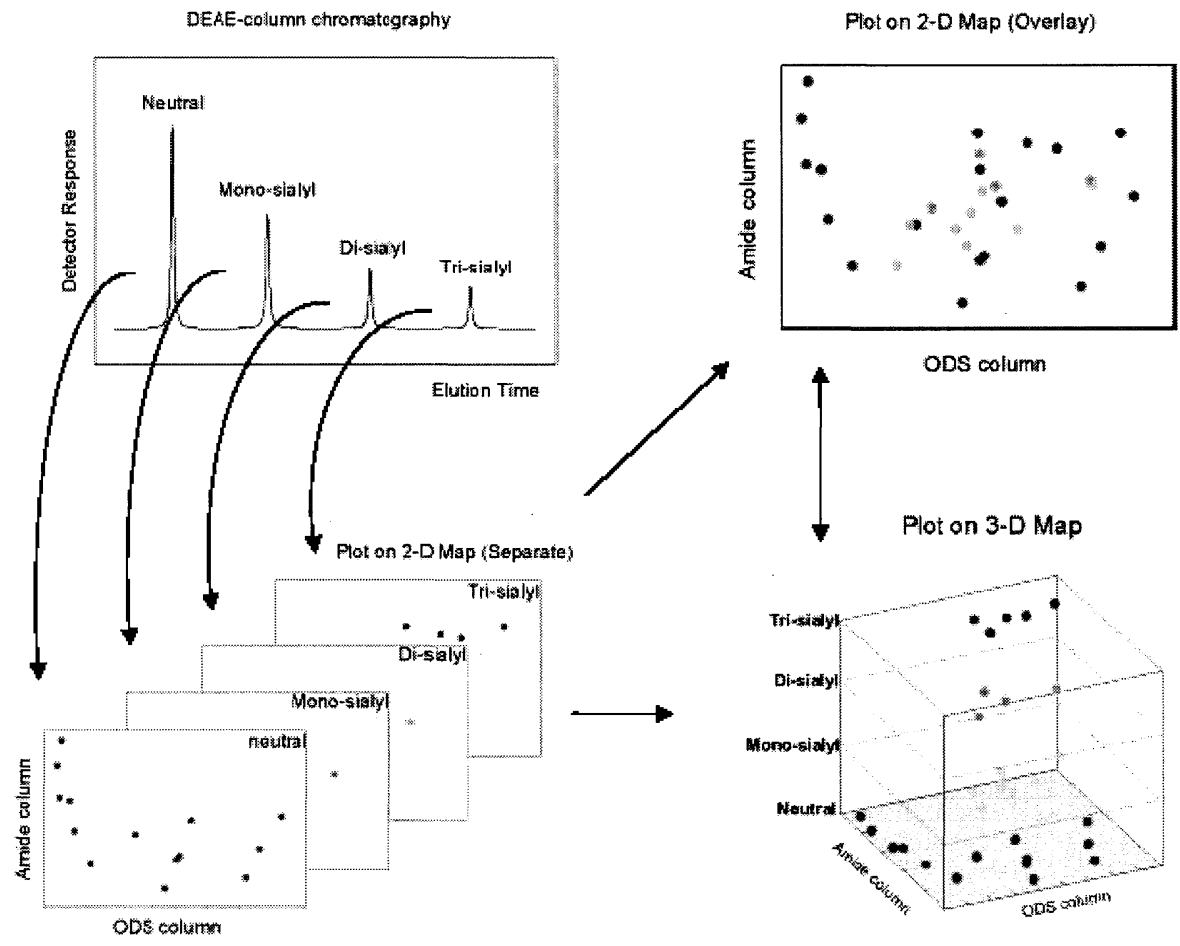

Fig.2. The make-up of the 2-D/3-D map. 
(4) The coordinates of the sample PA-glycans are plotted on the 2-D map.

(5) For each group of different sialylation, the above processes (2)-(4) are repeated.

Let us explain further using Fig. 2.

(a) and (b): When all the coordinates are plotted for each sialylation group, a 2-D map is created for each of these groups
(4) 試料 PA 糖鎖の、 $\mathrm{X}$ 軸および $\mathrm{Y}$ 軸の座標を、2-D マップ 上にプロットします。

(5) 同様にしてDEAEカラムで分離されたシアル酸数の異な る各ピークをそれぞれ上記の (2)-(4) の方法で分離し 3-D マッ プを作り上げます。

図 2 で説明します。

3-D マップ法の最初のカラムである DEAE カラム (a) で分

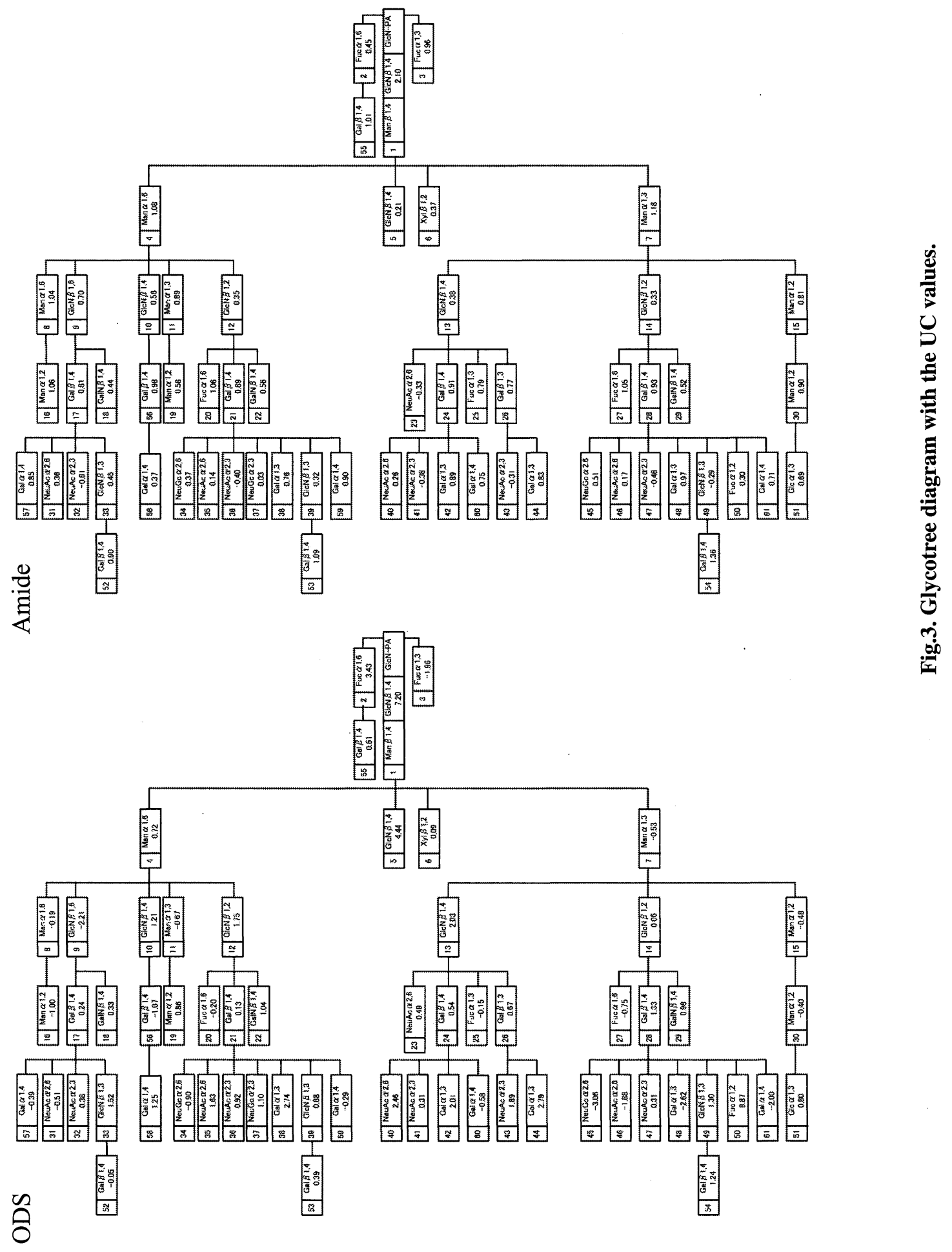


separated by the DEAE column.

(c) and (d): It is important that for each 2-D map the HPLC elution conditions used (the composition of buffers and gradient changes ) to obtain the $\mathrm{X}$-and Y-coordinates are completely identical, so the coordinates can be transposed from layer to layer. If we plot all the coordinates from all the layers on a single 2-D map, the resultant map is very confusing. To avoid such confusion, 3-D plotting consisting of layers of 2-D maps is introduced, as shown in (d).

\section{A-4. Analyses of N-Glycan Structures}

$\mathrm{N}$-glycan structure can be expressed by a tree-like form which spreads its branches on a trunk of a tri-mannosyl core structure. The approximately 500 structures so far documented can be expressed as a Glycotree Diagram that joins all 61 different units of sugar residue(Fig. 3).

The structure of an unknown $\mathrm{N}$-glycan is estimated by comparing its position on the 3-D map with the positions of the PA- reference $\mathrm{N}$-glycans plotted on the 2-D map.

(1) A few candidates whose coordinates coincide with those of the sample PA-glycan within allowable error $( \pm 5 \%)$ are chosen by a computer search.

(2) The sample PA-glycan and one of the candidate reference PA-glycans are co-injected into two different HPLC columns to confirm a single peak.

(3) The sample PA-glycan and the candidate reference PA-glycan are simultaneously digested with several glycosidases. Their elution positions are compared again. The comparison is continued until both PA-glycans yield the common trimannosyl core. (See references 1, 2 and 3).

We will continue our explanation using Fig. 4.

It is sometimes necessary to go beyond a direct compari- 離した試料のピークは、(b) のようにそれぞれ別々の (中性糖 鎖、モノシアリル糖鎖、ジシアリル糖鎖等の) 2-Dマップ上に目 盛ります。(b) で別々のチャートに目盛った座標は、(c)のよう に 1 枚のマップに重ねて表示することも可能です。それは、中 性糖鎖もシアリル糖鎖もマップ法の分離条件 (緩衝液の組成、グ ラジエントの変化)が全く同一なので、サンプルの数が少なけれ ば、1枚のマップに目盛ることもできるのです。しかし、試料 数が多い場合は、(d) のように別々にしたほうが重なる点が少な いので、原則としてシアリル糖鎖はDEAE カラムで分けた後そ れぞれ別のマップで同定したほうがよいでしょう。(c)で重なっ ていた点は、(d) ではすべて完全に分かれています。

\section{A-4. 糖鎖構造解析法}

$\mathrm{N}$ 型糖鎖の構造は、トリマンノシルコアを幹として枝を広 げた樹の形状にたとえられます。現在登録された 500 個近い既 知糖鎖の構造は、すべて 61 種の糖残基ユニットの組み合わせに よる糖鎖ツリーとして書き表すことができます (図 3)。

個々の試料の糖鎖構造解析法は、試料の PA 糖鎖のマップ 上の位置を、既知の標準 PA 糖鎖の位置と比較することで構造 を推定するものです。その方法の要点は、

1. まず得られた試料 PA 糖鎖の座標值から $\pm 5 \%$ 程度の範 囲にある標準糖鎖を検索して、幾つかの候補を選び出します。

2. 試料 PA 糖鎖と、選ばれた候補の標準糖鎖の 1 つとを、 ODS およびアミドの HPLCカラムによって共打ち試験を行いま す。両者が完全に 1 つのシンメトリーなピークにならない時は 試料と標準品は同じ構造ではありません。

3. 試料と標準品が共打ちで完全に一致しなかった時はさら にエキソグリコシダーゼ消化によって試料の糖鎖構造を変化さ せ、その都度適当な標準品と共打ちを行い比較します。最終的に 糖鎖がトリマンノシルコアに一致すれば同定は完全です。糖鎖 構造解析法の詳細は文献を参照してください。参考文献 $(1 、 2 、 3)$ 。

図 4 に実例を示します。

試料 PA 糖鎖のマップ上での位置 (緑十字) が、上図のよう

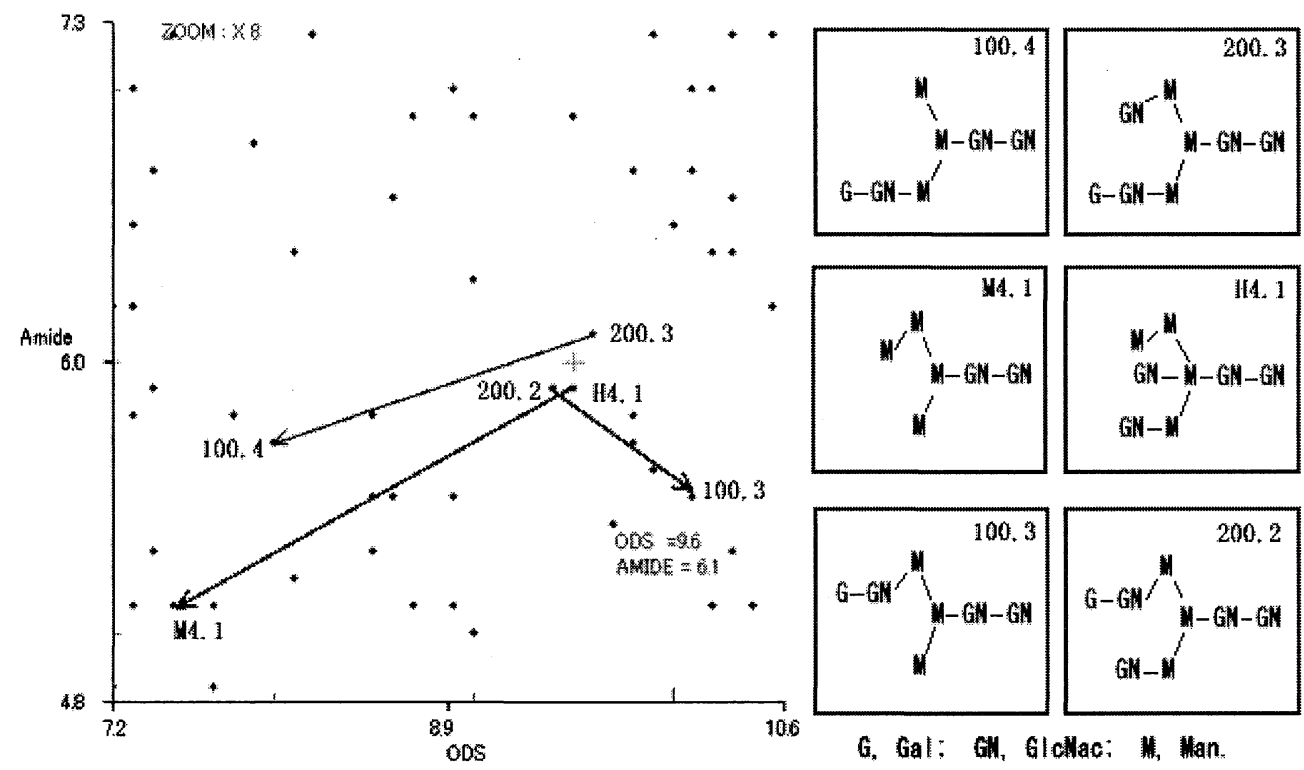

Fig.4. Structural analysis using a glycosidase digestion. 


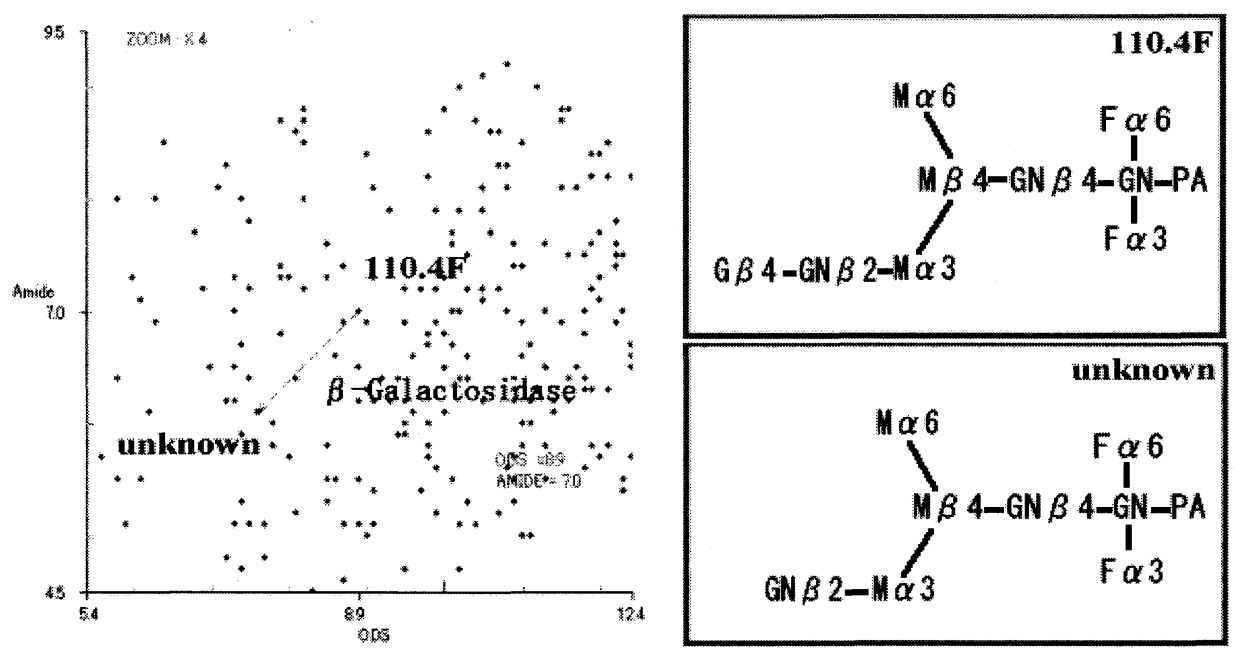

G. Gal: GN, GloNAc: M, Man.

Fig.5. Prediction of coordmates of an unidentified PA-glycan based on the UC values.

son of the GU. For example, the coordinates of an unknown sample (green cross) are placed among three known structures (red dots), and the molecular weight of the three references are all the same. In these cases, co-injection with a reference PAoligosaccharide is the most reliable solution. Moreover, a digestion method using several glycosidases is very useful. Although the elution positions of the three candidates are very close, after $\beta$-N-acetylhexosaminidase digestion, the elution positions of the resultant three $\mathrm{N}$-glycans disperse as illustrated in Fig. 4. Therefore, we can establish the originally unknown structure by a series of transformations.

\section{A-5. Parameterization of Unit Contribution}

The basic assumption used in the paramerterization of unit contribution is that the elution position of a given PA-glycan is represented by the sum of the contribution of each component monosaccharide unit (unit contribution $=\mathrm{UC}$ ). The calculation to obtain UC parameters was carried out by linear multiple regeression analysis. All 61 different UC values obtained for ODS and amide columns are diagrammatically expressed in GU as shown in Fig. 3.

The purpose of the parameterization of UC is as follows:

(1) From a given structure, the GU value of the N-glycan can be assumed.

(2) These calculated UC values are useful in predicting glycan structure from an observed GU on the 2-D map.

Let us explain case (1) using Fig. 5.

Although code No. 110.4F (ODS 8.9, amide 7.0) exists on the 2-D map, the smaller structure lacking galactose residue (unit number 28, see fig. 3) does not exist on the map. However, if we use the UC value of the galactose residue (ODS 1.3, amide $0.9)$, the position of this new structure on the map can be estimated easily.

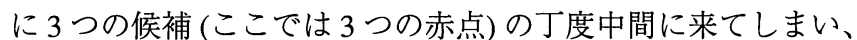
どれとも決められない場合があります。さらにこの 3 者は分子 質量も同一なので、区別がむずかしいケースです。こういう時 でも、試料とそれぞれの標準品とを HPLCに共打ちすれば、そ れだけで殆ど決まりますが、さらに酵素消化を行えば万人を納 得させることが出来ます。図 4 の右図のように 3 者を $\beta-N$ Acetylhexosaminidase ( $\beta$-HexNAcase) で消化するとマップ上で互 いに明瞭に離れますので、元のものがどれだったか迷うことは ありません。

A-5. Unit Contribution のパラメーター化

HPLCのカラムからの糖鎖の溶出位置は、規則性・再現性が あり、また、その溶出位置は、糖鎖ツリーを構成する各糖鎖残 基ユニット (現在は 61 種類)のカラムへの親和力 (Unit Contribution = UC) の合計であると考えられます。そこで、このUC 值 の大きさを重回帰分析を行って算出し数值化しました。パラ メーター化の目的は、以下の 2 つです。

(1) 糖鎖の構造式が与えられた時、それが既知の糖鎖でなく ても、マップ上のどのあたりに出てくるか、実験する前に大体 の見当がつく。

(2) 試料糖鎖の座標が、マップ上の既知ものと一致しなかっ た場合でも、その位置から、糖鎖の推定ができる場合がある。 実際これらのパラメーターの值を使って未知の糖鎖の位置 を予測した例を図 5 に説明します。

図 5 の右上の構造式 (コード番号 110.4F) については ODS 8.9 , アミド 7.0 という実測值が知られていますが、右下に示す ような、110.4Fから末端のガラクトース残基 (図 3 の糖残基工 ニット28) を除いた糖鎖のデータは記載がありません。しかし UC 值 (この場合は ODS 1.3, アミド 0.9) を利用すれば簡単にそ のマップ上の位置が ODS 7.6, アミド 6.1 というように推定でき ます。

\section{A-6. コード番号}

個々のPA 糖鎖に対してつけたコード番号の意味は図 6 を 参照して下さい。ハイフン (-)より右の数字は中性糖部分につい ての番号です。 


\section{A-6. Code Number}

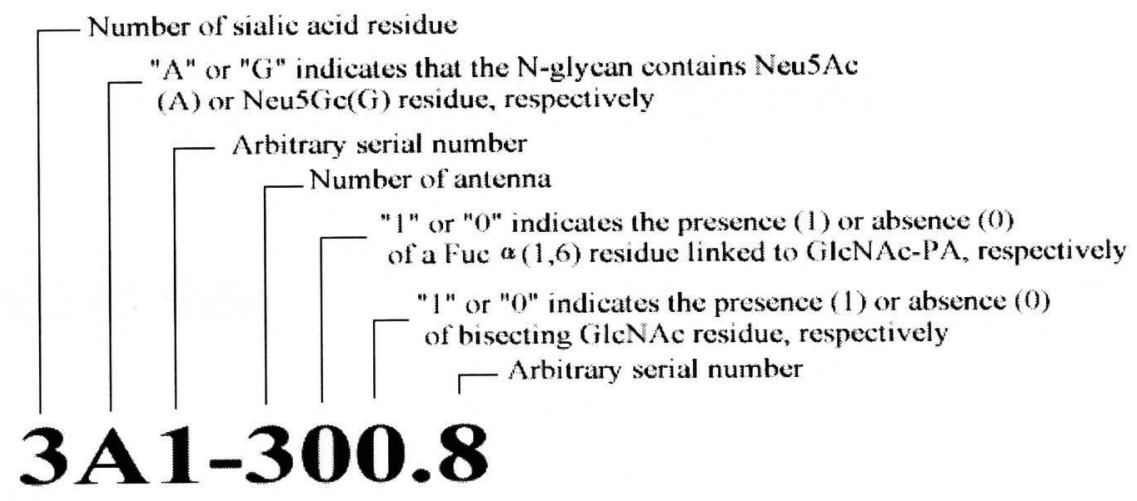

Fig.6. Code Number

\section{B. User Manual for GALAXY \\ B-1. Start-up Screen}

The screen in Fig. 7 is the basic view of the system displaying various tools available with this system. The system display consists of various text fields, buttons, combo boxes and checkboxes for the user to select different options and perform various functions.
B. GALAXYのユーザーマニュアル

\section{B-1. 画面配置}

図 7 のスクリーンは GALAXY の基本的な視界です。全て の解析はこのマップ上で可能です。この画面には、様々な処理 を提供するために、テキストフィールド、チェックボックス、 ボタン、チョイスボックスが配置されています。

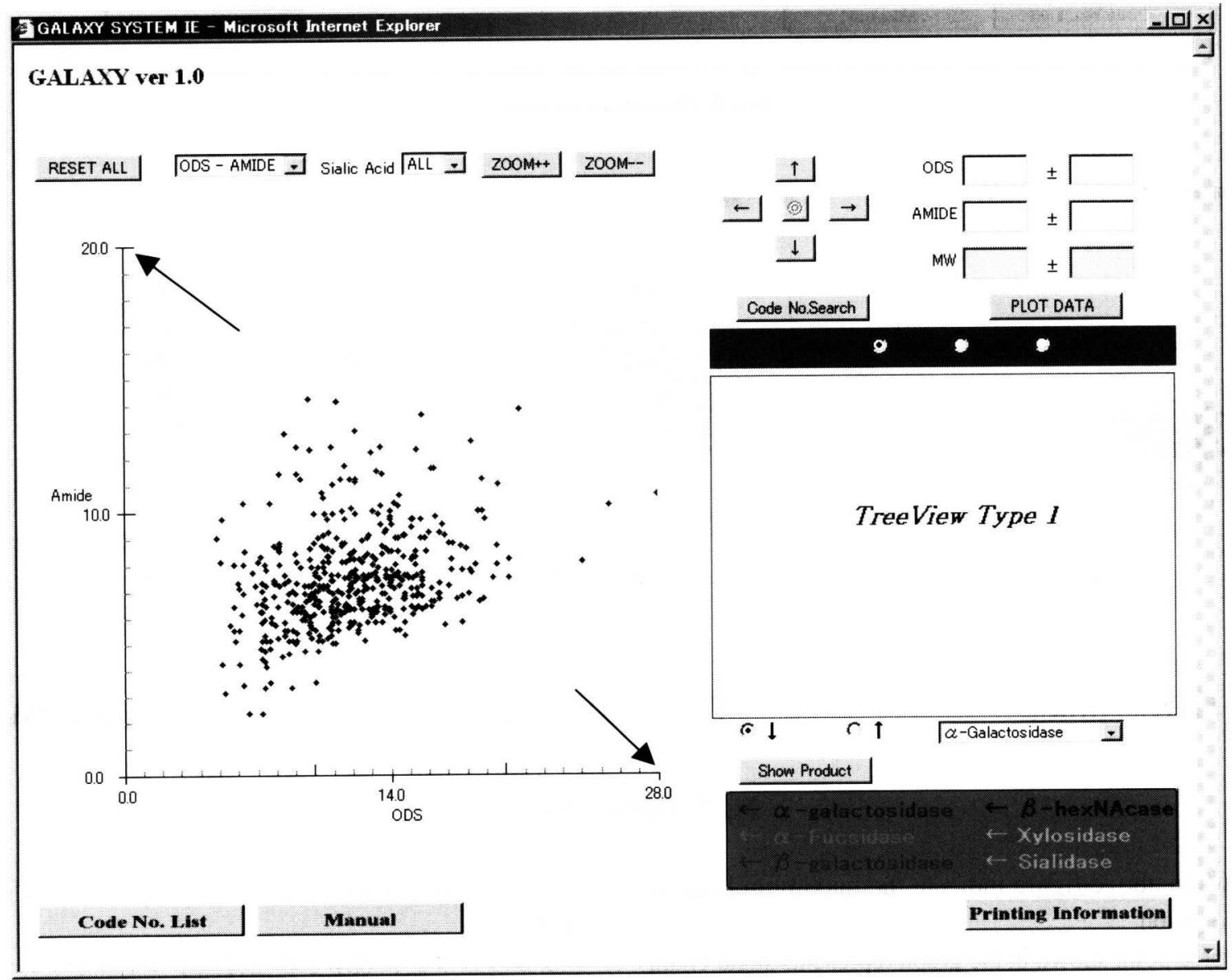

Fig.7. Start-up screen. 


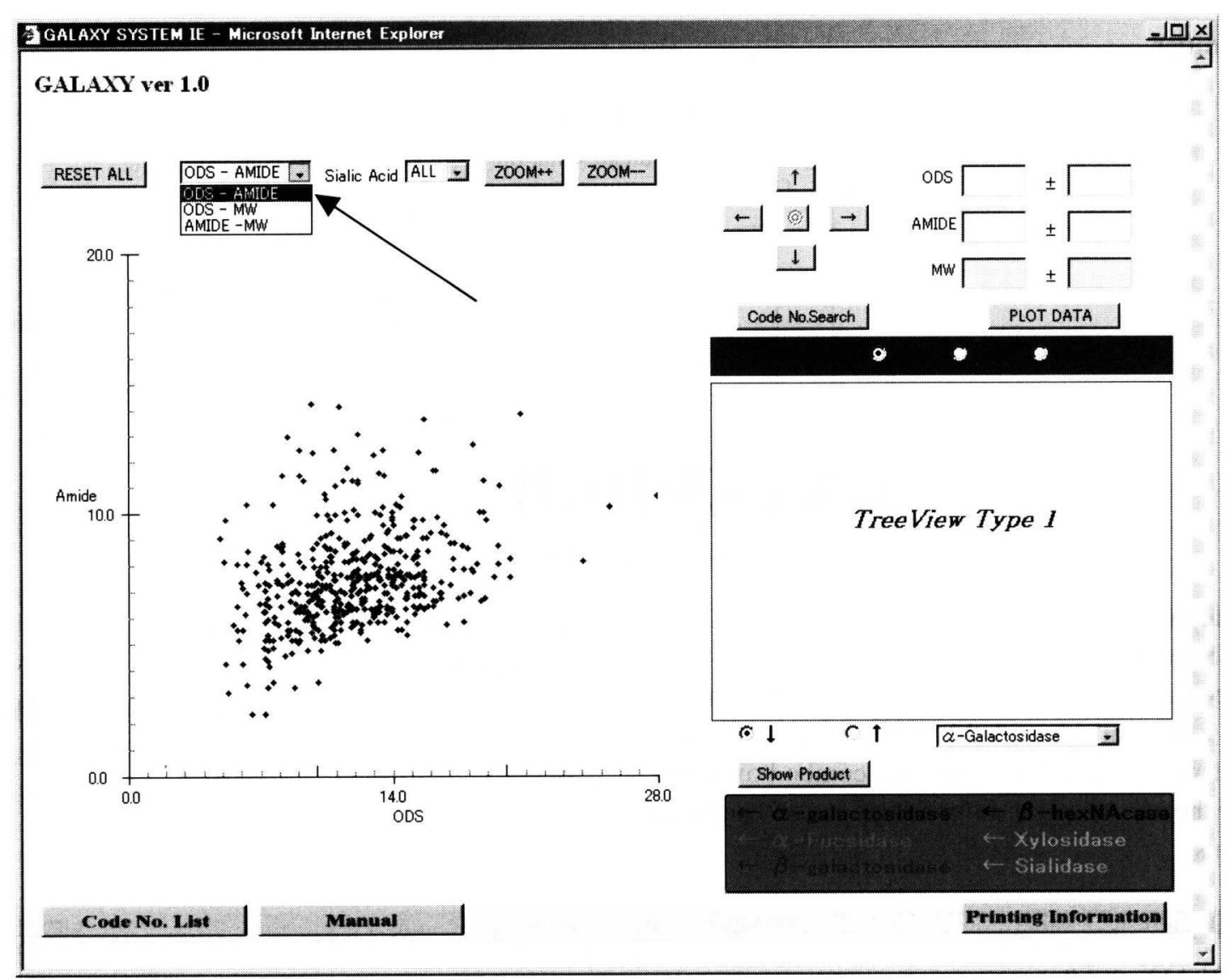

Fig.8. Graph selection

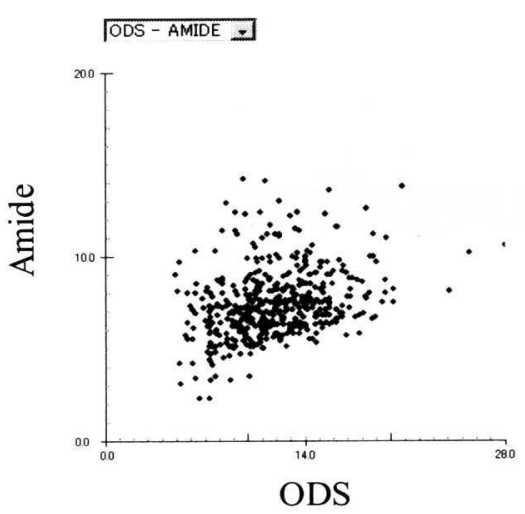

ODS-Amide

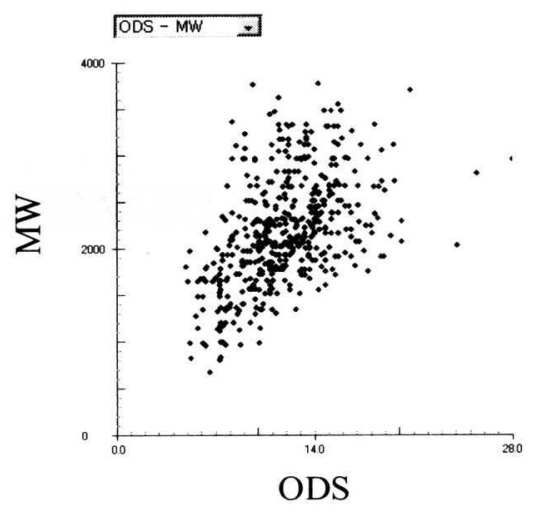

ODS-MW

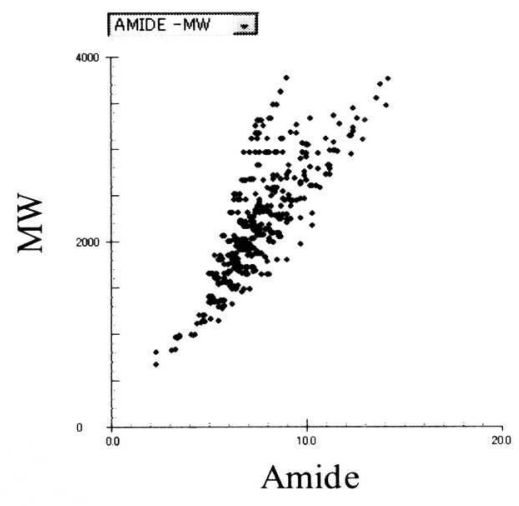

Amide-MW

Fig.9. Types of the axes.

Arrows in above figure indicate the maximum limit of ODS / Amide graph.

Each blue point shown in the graph represents sugar chain structures associated with that particular point.
以下、現在矢印で示されている領域をグラフマップと記述 します。

グラフマップに表示された青点 1 つ つがシステムに登録 されている糖鎖構造を示します。 


\section{B-2. Graph Selection}

By clicking the choice box (indicated by an arrow in Fig. 8), one of the three types of graphs can be selected. Molecular weight is referred to as MW in this manual. By default ODS Amide graph is selected and the same graph is displayed on the screen but the user can select ODS - Molecular weight or Amide - molecular weight graphs (Fig.8).

If the choice box selection is changed, $\mathrm{X}$ and $\mathrm{Y}$ axis values and limits also change according to the selected graph (Fig. 9).

Similarly by clicking on the Sialic Acid choice box, one of the SIX(6) types of the Sialic Acid (ALL, 0, 1, 2, 3, 4) can be selected. By default "all" is selected and the graph is drawn according to this default selection.

If the Sialic selection is changed, PA - glycans represented by the selected Sialic acid are displayed (Fig.10).

\section{B-3. Manually Inserted Data Display}

To display the Text Field data in the current graph click the mouse on "PLOT DATA" button (Fig. 11). According to the values entered in the Text Field various shapes are created. Text

\section{B-2. グラフ選択}

図 8 の矢印で示したチョイスボックスを変更して 3 つのグ ラフパターンから 1 つのグラフパターンを選択することができ ます。デフォルトの軸は ODS-Amide ですが、ODS-Molecular Weight と Amide-Molecular Weight も選択できます。Molecular Weightについては以下 MW と表記します (図 8)。チョイスボッ クスを変更すると、グラフマップの X-Y 軸が変更されます (図 9)。

同様の操作で、Sialic Acid のチョイスボックスを操作する ことが可能です。Sialic Acid チョイスボックスは ALL, 0, 1, 2, 3, 4 の 6 つから 1つを選択します。ALLがデフォルトとして設定 されています。

Sialic Acid を変更すると、選択したシアル酸数に反映して グラフマップに配置されている青点 (各糖鎖構造を示す) が減 少、増加します (図 10)。

\section{B-3. 実験データの表示}

実験デー夕を対応したテキストフィールド(図11)に入れて PLOTDATA ボタンを押してください。入力された值に対応し、 様々な形式でデー夕表示が行われます。
Sialic Acid $\mathrm{ALL}$

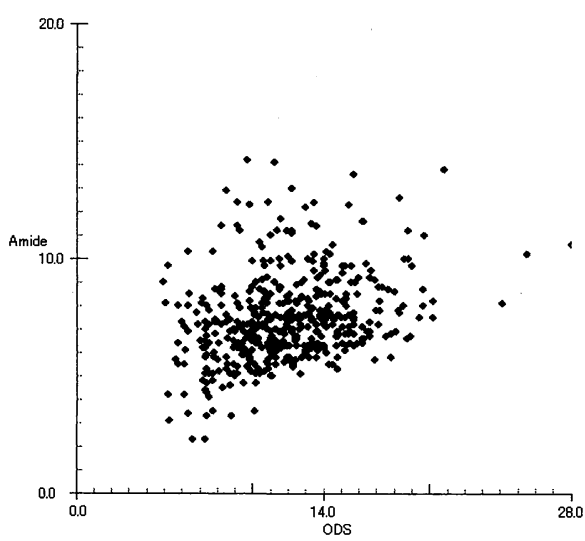

Sialic Acid $\longdiv { 2 = }$

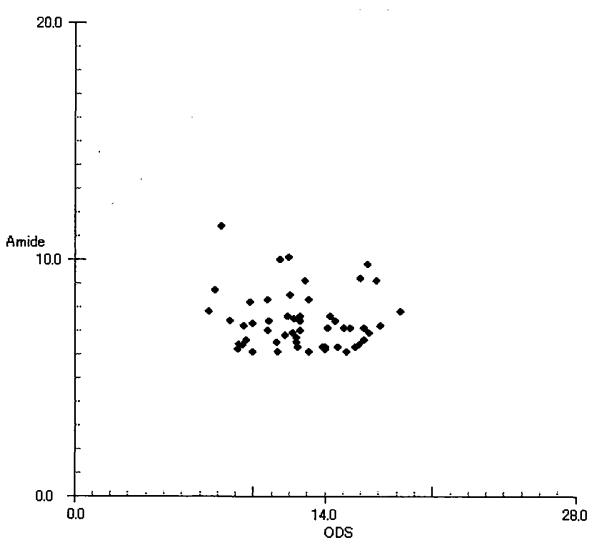

Sialic Acid 0

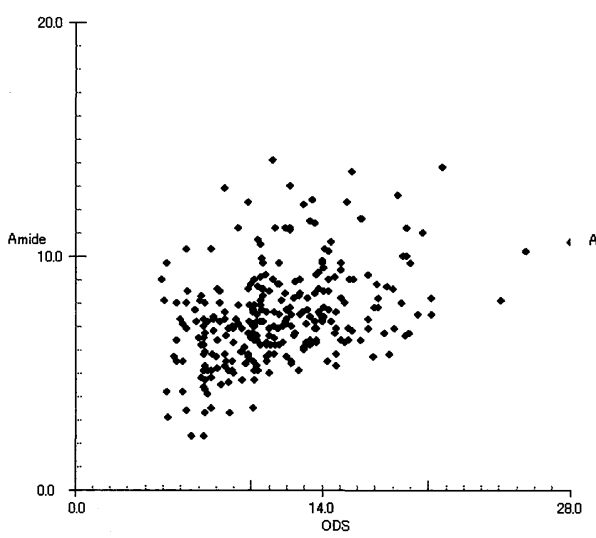

Sialic Acid $\longdiv { 3 \quad \square }$
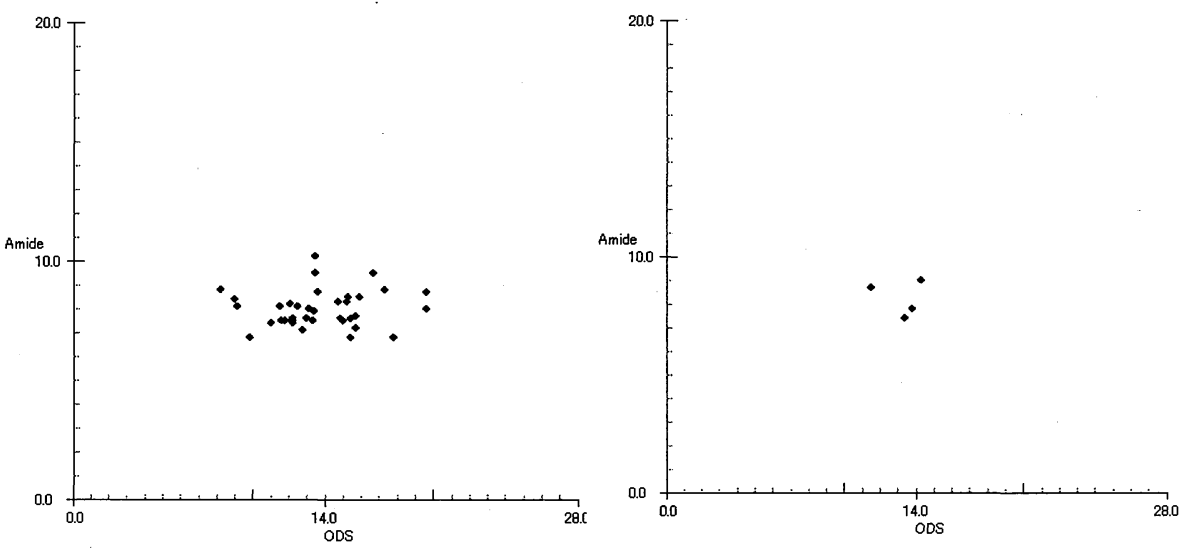

Sialic Acid 1

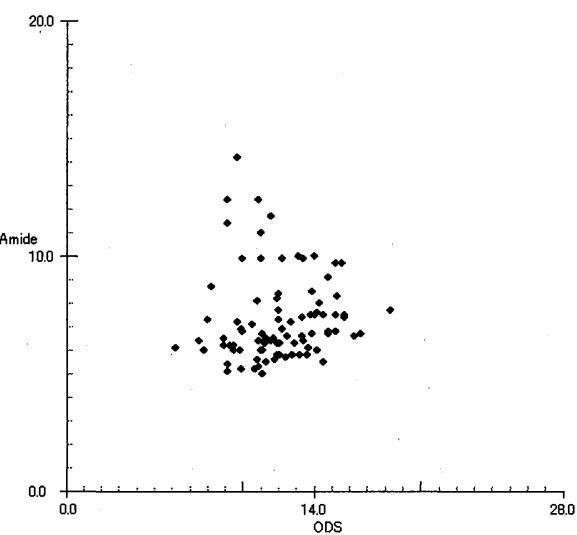

Sialic Acid $\longdiv { 4 \quad \square }$

Fig.10. Selection of the sialic acid numbers. 


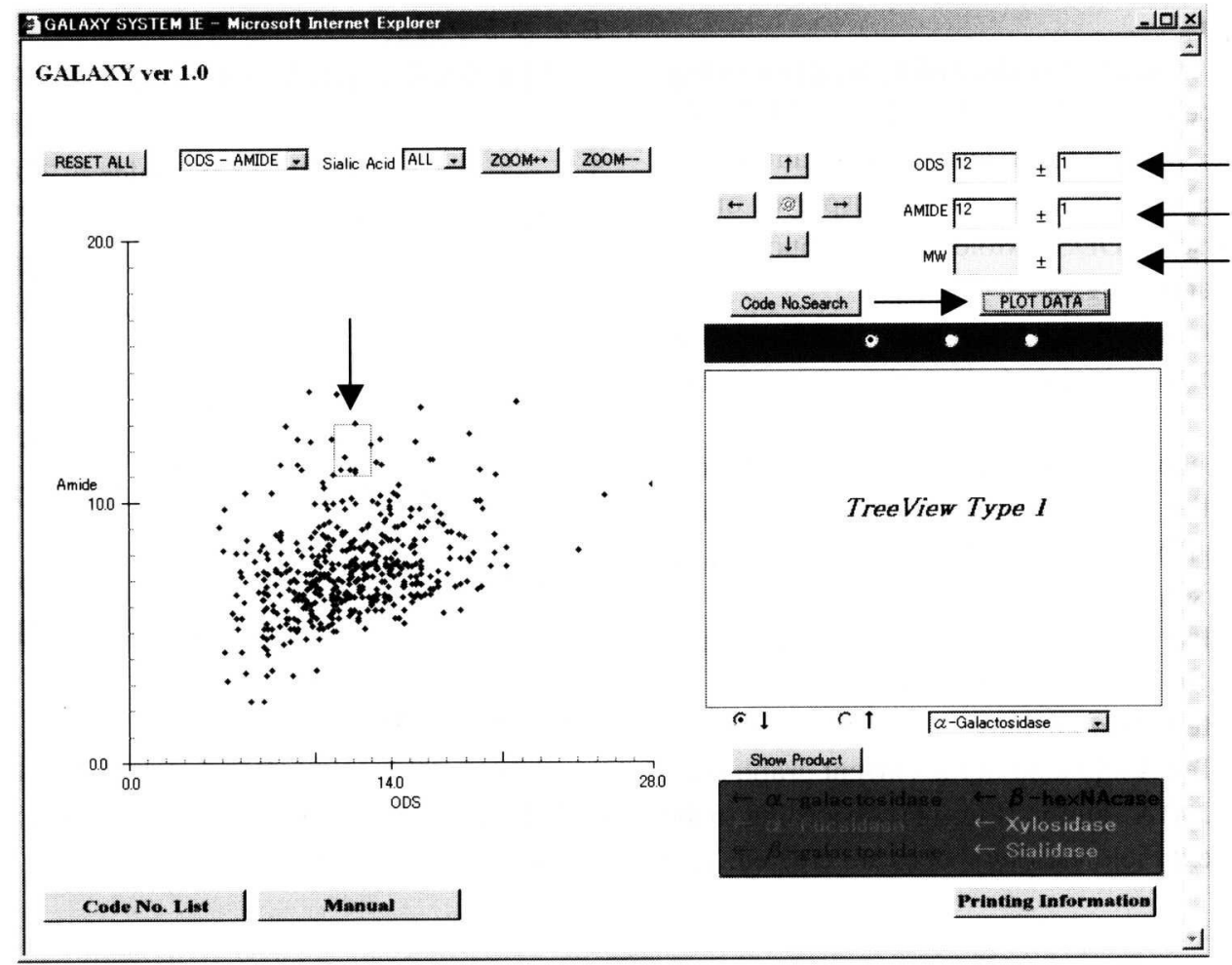

Fig.11. Manually inserted data display.

Fields are set 2 in a row and parallel to each other. Text Fields on the right side of the +- sign are error fields. These error fields are used to insert error factors related to the experiment data.

According to the values entered in the Text Fields various shapes are drawn on the screen as explained below -

Example: - ODS(x axis) - Amide(y axis)

\section{ODS (X axis) values are inputted}

A green line is drawn parallel to Y-axis at the ODS (X axis) value.

\section{Amide (Y axis) values are inputted}

A green line is drawn parallel to $\mathrm{X}$ axis at the Amide $\mathrm{Y}$ axis) value.

3. ODS ( $\mathrm{X}$ axis) and Amide ( $\mathrm{Y}$ axis) values are inputted.

A green plus sign is drawn at ODS ( $\mathrm{X}$ axis) and Amide ( $\mathrm{Y}$ axis) values. If this point has a sugar chain, that point is selected. (Refer User Manual 1.5)

\section{ODS ( $X$ axis) and ODS error are inputted}

A green line is drawn parallel to $\mathrm{Y}$ axis at ODS ( $\mathrm{X}$ axis) value along with 2 green lines drawn parallel to $\mathrm{Y}$ axis at (ODS (X axis) + error) and ODS (X axis) - error).

\section{Amide ( $\mathrm{Y}$ axis) and Amide error are inputted}

A green line is drawn parallel to $\mathrm{X}$ axis at Amide ( $\mathrm{Y}$ axis) value along with 2 green lines drawn parallel to $\mathrm{X}$ axis at (Amide ( $\mathrm{Y}$ axis) + error) and Amide (Y axis) - error). inputted

6. ODS ( $\mathrm{X}$ axis), Amide ( $\mathrm{Y}$ axis) and Amide error are

A green line is drawn with ODS ( $\mathrm{X}$ axis) and Amide ( $\mathrm{Y}$
テキストフィールドはそれぞれ並列に2つ一組で配置され ています。土の記号の右側は ODS, Amide, MW 各々の ERROR 成分を表します。

表示方法について

例：図 ODS (X軸)-Amide (Y軸)のグラフ

1. ODS (X值)のみを入力

ODS (X值)のポイントにY 軸に平行な緑線が表示される。

2. Amide ( $\mathrm{Y}$ 值) のみを入力

Amide (Y值)のポイントにX 軸に平行な緑線が表示される。

3. ODS ( $\mathrm{X}$ 值) と Amide (Y値)を入力

ODS (X值) と Amide (Y值) のポイントに緑十字が表示され る。もし、このポイントが既知糖鎖構造と一致する場合は、そ の構造を選択状態 (本マニュアル1.5)にする。

\section{ODS (X值) と ODS-error を入力}

ODS (X值)のポイントにY Y 軸に平行な緑線が表示される。 更に、ODS (X值) から (+) ODS-error、(-) ODS-error の位置に範 囲を示す緑線が表示される。

\section{Amide (Y值) と Amide-error を入力}

Amide (Y值)のポイントにX 軸に平行な緑線が表示される。 更に、Amide (Y值) から (+) Amide-error、(-) Amide-error の位置 に範囲を示す緑線が表示される。

6. ODS ( $\mathrm{X}$ 值) と Amide ( $\mathrm{Y}$ 值) と Amide-error を入力 ODS (X值)を基準として Amide (Y值) + Amide-error から 


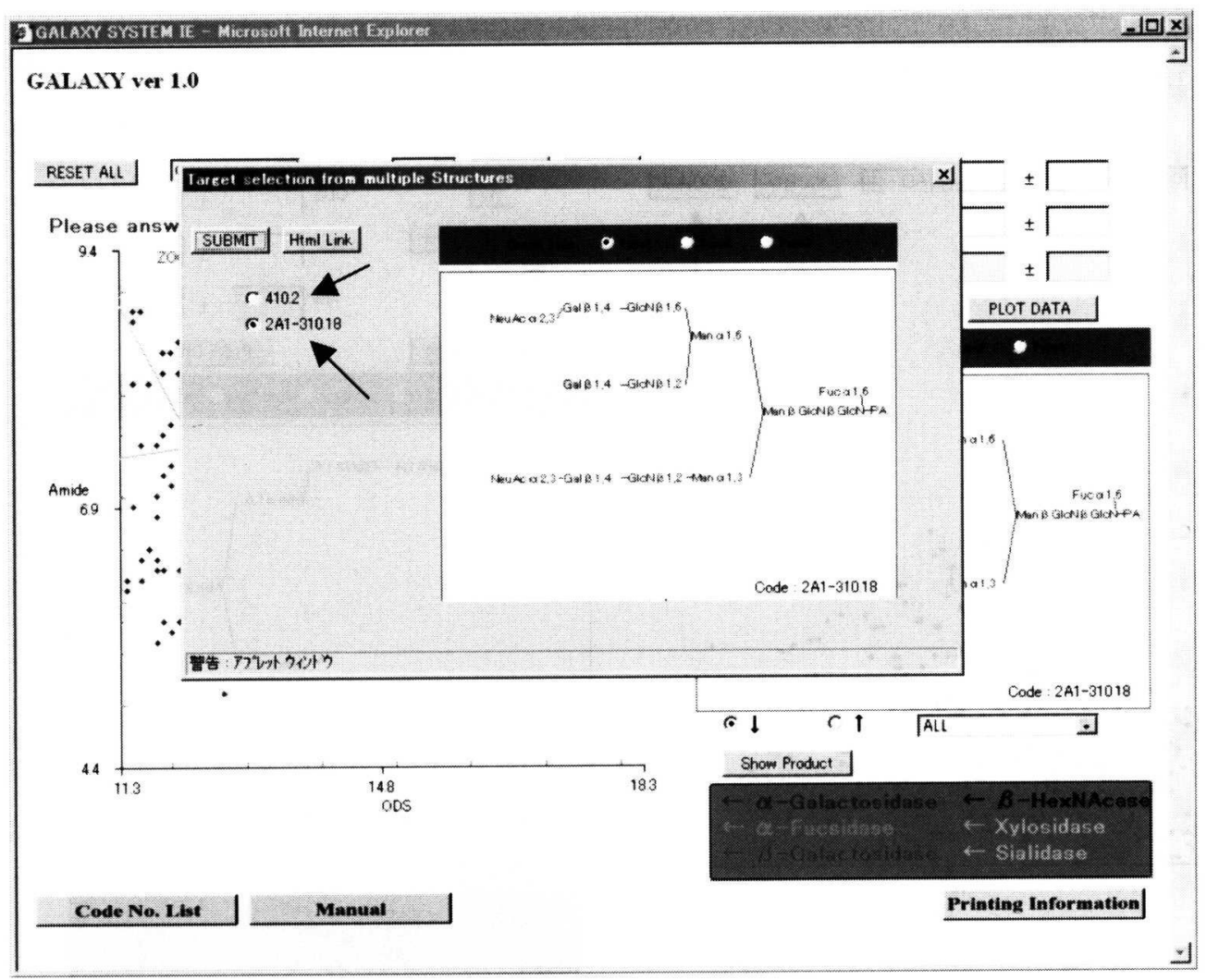

Fig.12. Mouse click.

axis) as base (center) from (Amide (Y axis) + error) to (Amide (Y axis) - error).

\section{ODS ( $\mathrm{X}$ axis), Amide (Y axis) and ODS error are} inputted

A green line is drawn with ODS ( $\mathrm{X}$ axis) and Amide ( $\mathrm{Y}$ axis) as base (center) from (ODS (X axis) + error) to (ODS (X axis) - error).

\section{ODS ( $\mathrm{X}$ axis), Amide ( $\mathrm{Y}$ axis), ODS error, Amide error are inputted}

ODS ( $\mathrm{X}$ axis) +/- error and Amide ( $\mathrm{Y}$ axis) +/- error are set as 4 points of the square and a green square is drawn.

In the case of ODS (X axis) - MW (Y axis) and Amide (X axis) - MW ( $\mathrm{Y}$ axis) the above 8 rules are also used to draw various combinations according to the values entered by the user.

\section{B-4. Mouse Click}

If the mouse is clicked on the blue point in the graph, the sugar chain related to that point is displayed on the right side of the screen (Fig. 12).

If the clicked blue point turns red, it represents that the selected point has a related sugar chain and sugar chain is displayed on the right side of the screen. Mouse click draws a red point or red plus sign on the screen. The meaning of these signs is as follows,

Red Point - Sugar chain exists with the clicked point.

Red Plus sign - Sugar chain does not exist with the clicked point.
Amide (Y值) - Amide-errorまで緑線が表示される。

7. ODS ( $\mathrm{X}$ 值)と Amide (Y值) と ODS error を入力

Amide (Y值) を基準として ODS (X值) + ODS-error から ODS (X值) - ODS-error まで緑線が表示される。

8. ODS ( $\mathrm{X}$ 值)、Amide (Y值)、Amide error、ODS error 入力

ODS (X值) \pm ODS error と Amide (Y值) \pm Amide error の 4 点 を利用して緑四角が表示される。(例：上図、グラフマップ上に 配置された四角)

ODS (X值) -MW (Y值)、Amide (X值) -MW(Y值) のグラフで も上記の $1 \sim 8$ のルールによって処理されます。

1〜8の入力に一致しない場合の処理は無効となります。

B-4. マウスクリックについて

図 12 のグラフマップ上でマウスの左ボタンをクリックする と、そのポイントにある糖鎖構造を選択することができます。 クリックすると、印が表示されますが、

赤点：クリックしたポイントの構造が選択された。

赤十字：クリックしたポイントに構造が存在しない。 を意味しています。

クリックするポイントによっては、2つ以上の糖鎖が重複し 


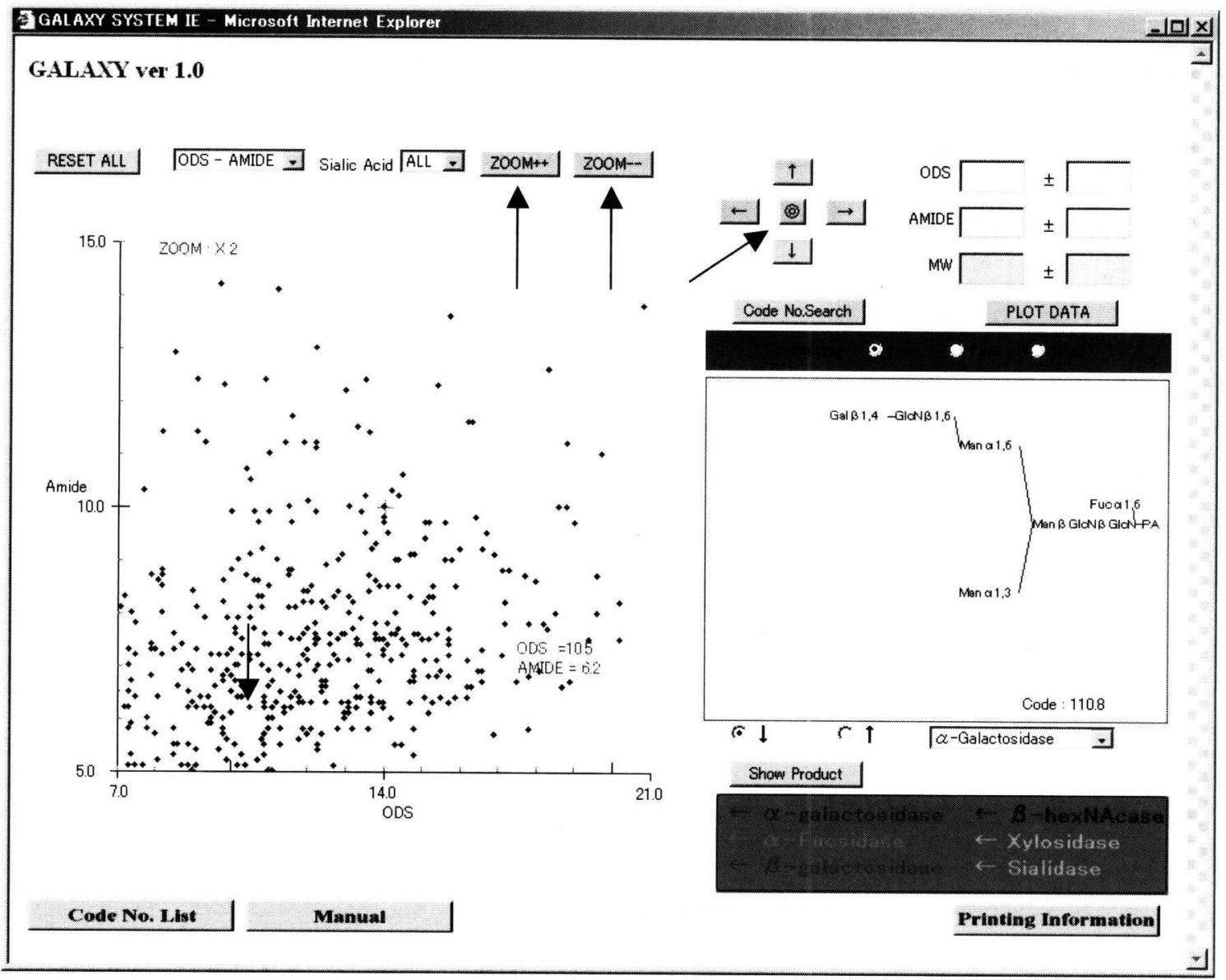

Fig.13. ZOOM++ / ZOOM--

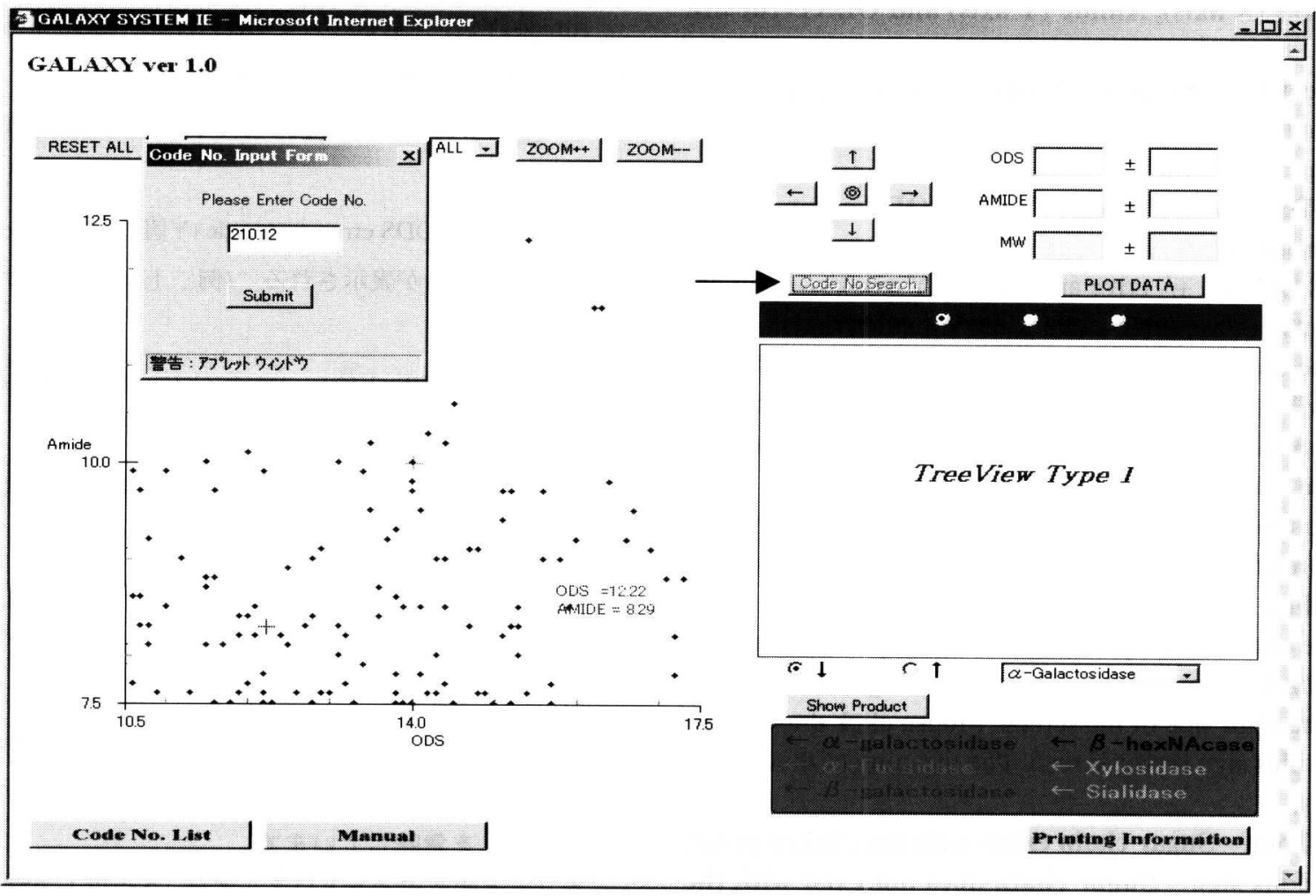

Fig.14. Code No. search. 
It may also be the case that the clicked point has more than one structure associated with it. In this case a dialog as shown in the figure is displayed. The user can determine the sugar chain of interest and the selected sugar chain will be displayed for further reference. If a red point is displayed at the clicked position, the sugar chain related to that point is displayed on the Structure panel (right side of the screen).

\section{B-5. ZOOM++ / ZOOM-}

The graph can be zoomed or compressed by pressing the Zoom++ / Zoom--button (Fig. 13).

Zoom and compression is always carried out with reference to the center of the graph.

Example: In the image shown above RED POINT represents the point selected by the user. In the above case the zooming will be done according to $y$ (amide) $=10.0$ and $x$ $($ ODS $)=14.0$. Zooming can be done up to X8. The limit for compression is $\mathrm{X} 1$.

Tip: To zoom (compress) with respect to the selected point, select the point and press Center button(@(double circle)). This will bring the selected point to the center of the graph. Then press the ZOOM++ (ZOOM--) button.
て存在します。その場合、図 12 のような選択画面が起動します ので、矢印で示したボタンを変更して、選択する糖鎖構造を決 定してください。

グラフマップ上に赤点が存在する場合、右側の構造表示パ ネルに現在選択している糖鎖構造が表示されます。

\section{B-5. 拡大・縮小}

図13に㧍いてグラフを拡大・縮小するにはZOOM++・ ZOOM--ボタンをクリックします。

拡大・縮小処理は常にグラフの中心点を基準に処理されま す。

例：上図の赤点はユーザが選択したポイントです。

ZOOM ボタンをクリックするとXは14.0、Yは 10.0 のポ イントを中心として拡大(縮小) されます。

選択したポイントを中心に拡大するためには、センターボ タン（○：選択ポイントを中心に移動）をクリックして中心点 を変更後、ZOOM++ボタン (ZOOM--ボタン) を押してくださ い。

拡大の限界は 8 倍、縮小の限界は 1 倍に設定されています。

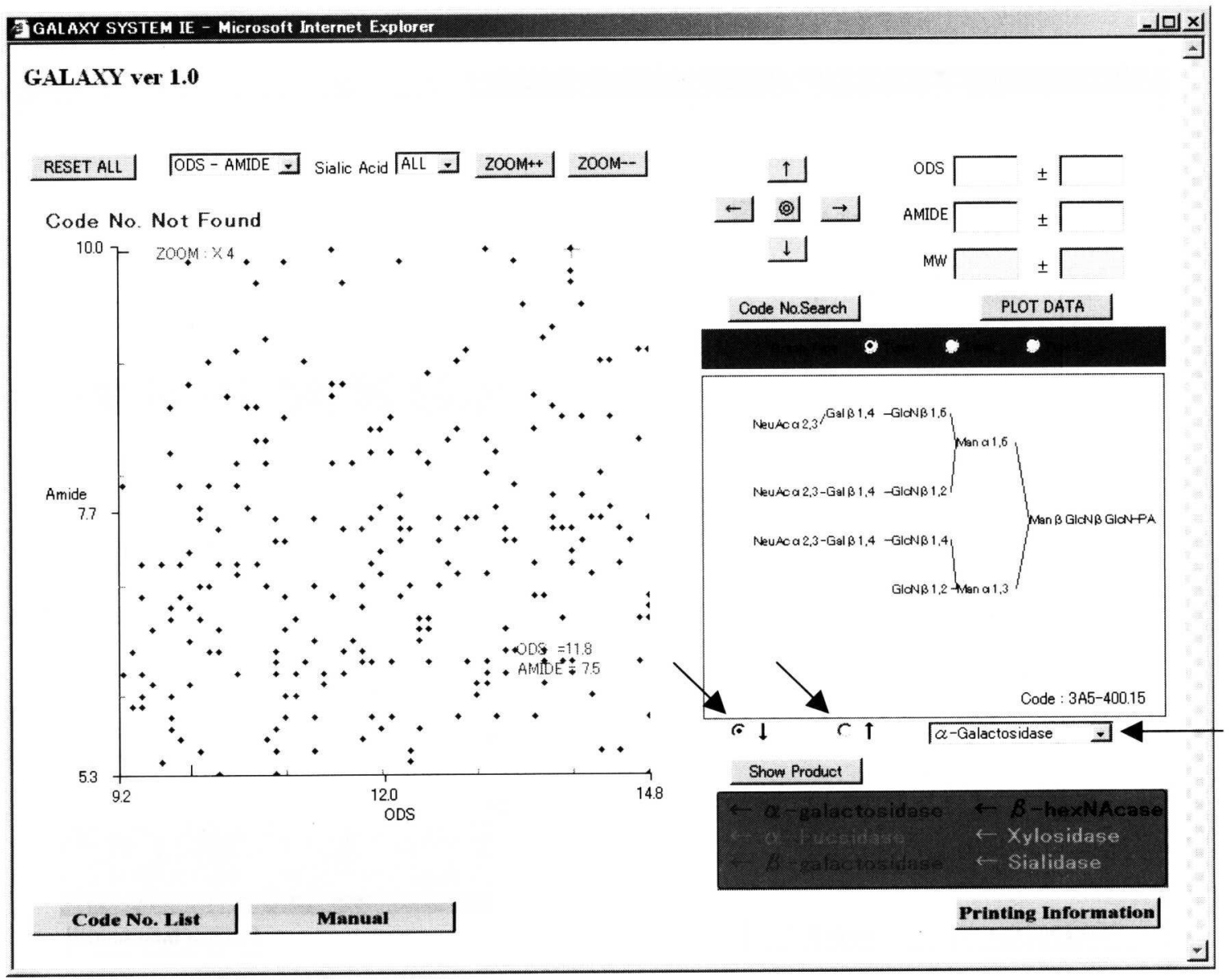

Fig.15. Product/precursor selection. 


\section{B-6. Code No. Search}

This button is used to search the PA-glycan according to the code number associated with that PA-glycan (Fig.14). On pressing this button, new dialog will pop up as shown in the figure. The user can enter the Code to be searched, in the text field of the popped up dialog and click submit button or press Enter. If the code entered by the user is available in the data, the product representing that code will be selected (that point will become red) otherwise an error message will be displayed. The user input is case insensitive.

\section{B-7. Product / Precursor Selection}

Checkboxes are used for the Product and Precursor selection (Fig. 15). The default selection is SHOW PRODUCT (downward arrow). For Precursor simply click the other checkbox and select the precise enzyme. Then press Precursor button.

Downward arrow (Product) - default selection

Upward arrow (Precursor) - user can make this selection.

If the precursor checkbox is selected (upward arrow), the button label will change to Precursor. Arrows will be drawn according to the selected choice box option and the selected checkbox.

\section{B-6. コード番号による検索}

Code No. Search ボタンは 図 14 に示すように、コード番号 によって糖鎖構造を検索するために利用します。このボタンを クリックすると、図のようにCode No. 入力用のダイアログが表 示されます。ダイアログに検索したい Code No．を入力して Submitボタンをクリックしてください。

入力された Code No. に対応したデータが存在する場合は その糖鎖が選択状態 (赤点で表示) となります。

検索処理は大文字・小文字に関係なく検索されます。

B-7. Product / Precursor の選択

酵素処理 Box で現在選択されている糖鎖を処理する酵素を 選択することができます (図 15)。また、図15 の矢印で示されて いるチェックボックスを使って酵素処理 Product や Precursor を 選ぶことが可能です。

Product 处理とは現在選択している糖鎖の消化酵素による通 常消化です。

Precursor 処理とは現在選択している糖鎖構造を基準とし て、消化酵素が利用される前の全ての構造を予測します。

$\downarrow$ ：選択状態が Product (デフォルト)

$\uparrow$ ：選択状態が Precursor

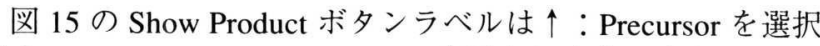
すると Show Precursor のラベルに変更されます。また、Show Product ボタンの下に配置されているカラー説明ラベルも変化し ます。

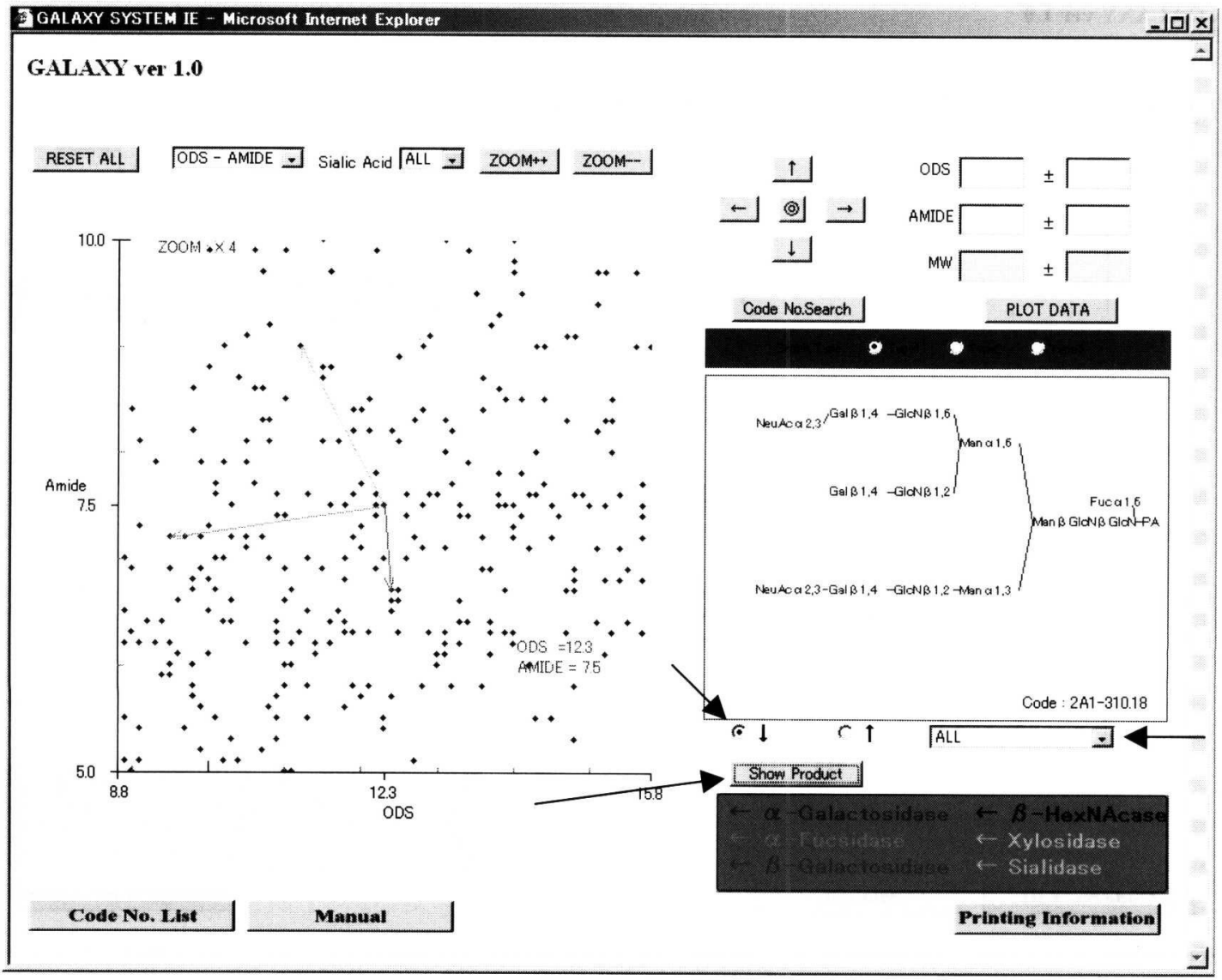

Fig.16. Product/precursor display. 


\section{B-8. Product / Precursor Display}

The button is used to draw product and Precursor arrows according to the selection of checkboxes (Fig. 16). If the product checkbox (downward arrow) is selected this button will read as Show Product. If Precursor checkbox is selected (downward arrow), this button will read as Precursor. Select the appropriate checkbox. Select appropriate enzyme type and press this button.

According to the selected enzyme, arrow color is set as shown in the color palette in the graph at the right bottom of the screen.

\section{Product: -}

In Show Product case if the product is available with the selected enzyme, an arrow will be drawn otherwise an error message will be displayed. If selected Oligosaccharide has a cut site but the product is unknown, a Dialog box will pop up asking whether to display unknown data or not. If the user selects to display data, an arrow (dotted line in this case) will be drawn to the product and as the product is unknown, a black point will be displayed as the product. User can select this product (black point) by clicking the mouse on it but cannot draw an arrow from this unknown product. User can double click the unknown point to see the Structure information, associated with this unknown product. If the unknown structure is a multiple point, multiple point selection dialog will pop up and the user can select from the Multiple products (known / unknown).

If from enzyme choicebox ALL option is selected and arrow button is pressed all the products related to all enzyme types are displayed.

\section{B-8. Product / Precursor の結果表示}

図16の Show Product および Show Precursor のボタンをク リックすると、消化酵素チェックボックスにて選択されている 酵素での Product、Precursor 処理の結果が上図のように表示さ れます。

結果はボタンの下部に配置されているカラーに対応した矢 印となります。

Product 処理 :

Product ボタンをクリックした時に確認用のダイアログが表 示されることがありますが、現在登録されていない糖鎖構造の 表示・非表示の確認です。YES を選択すると点線の矢印が表示 され、矢印の先端に黒点が配置されます。

NO の場合表示されません。

黒点はシステムに登録されていない未知糖鎖を表します。

黒点の糖鎖構造は選択することができ、詳細 HTML ページ も表示できますが、黒点からの Product、Precursor 処理はできま せん。

黒点が重複している場合は、重複処理ダイアログによって 選択することが可能です。

消化酵素チョイスボックスには ALL 項目が配置されていま す。

ALL を選択し、Product ボタンをクリックすると、現在登録 されている消化酵素に対応する全ての矢印が描かれます。

ALL の場合でも登録されていない糖鎖構造の表示・非表示 確認ダイアログが表示されることがあります。

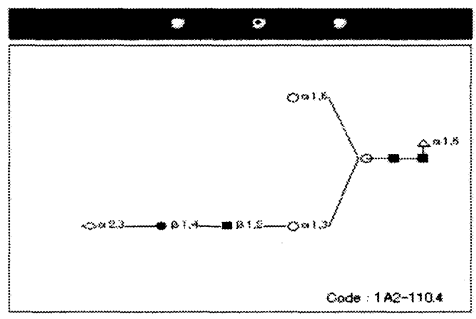

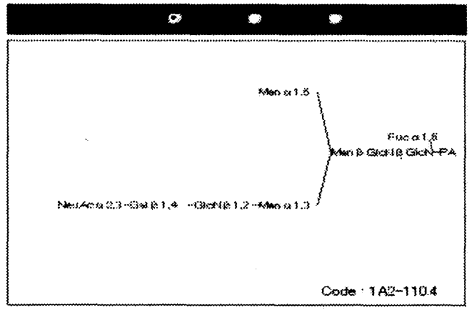

\section{(a) type 1}

\section{(b) type 2}

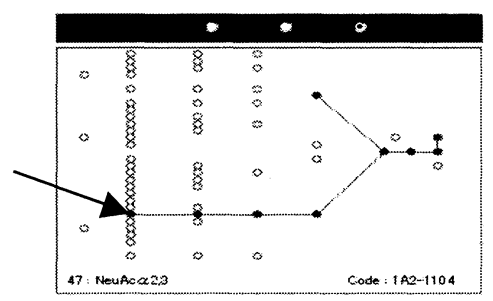

\section{(c) type 3}

Fig.17. Tree draw. 
If any of the enzyme type product has unknown data dia$\log$ will pop up. All the unknown products are shown if the user presses YES button on the dialog window else if the user presses NO button none of the unknown products are shown but all the known products are shown.

\section{Precursor: -}

For displaying the precursor, select an appropriate enzyme from the choice box and press Precursor button. All the precursor products are displayed. Red lines indicate an unknown product and Black lines indicate known products. Here Known product means the products currently available with this system.

\section{B-9. TreeDraw}

The structure shown at the right lower corner of the System is called TreeDraw (Fig. 17).

TreeDraw represents the Structure of the selected PAglycan. 3 Types of structure presentations are available with this system. The user can select any one type at a time by selecting radio button at the top of the tree draw.

Type 1 - Textual representation

Type 2 - Symbolic representation

Type 3 - Complete sugar chain illustration

In type 2 and 3 the user can click on the Unit to see the information related to that unit.
ALL の場合、YES を選択すると、点線矢印と実線矢印の 2 つのタイプが表示されます。

$\mathrm{NO}$ を選択すると、既知の糖鎖構造への実線矢印のみが表示 されます。

Precursor 処理 :

Precursor ボタンをクリックすると、選択した消化酵素が利 用される前の、既知および未知糖鎖からの矢印を描きます。

未知からの矢印は赤線で表示され、既知からの矢印は黒線 で表示されます。

Precursor 処理の場合は、消化酵素 ALL を利用することは出 来ません。

\section{B-9. 簡易構造表示 (TreeDraw)}

グラフマップ上の右側には常に 図 17 のような簡易糖鎖構 造表示パネルが配置されています。

1つの糖鎖構造ポイントが選択された場合、選択された構造 式がパネル上に表示されます。

表示パターンは、 type1, type2, type3 (図 (a)(b)(c)) の3つが あります。

Type1：文字による表現 (デフォルト)

Type2：記号による表現

Type3 : 全ての糖鎖樹形図を糖鎖ユニットの有無に関係な く確認できる。

Type2 Type3 は上図 (c) の矢印で示したように、各糖鎖 Unit をクリックすることにより、その糖鎖ユニットの情報を左下に 表示することが可能です。

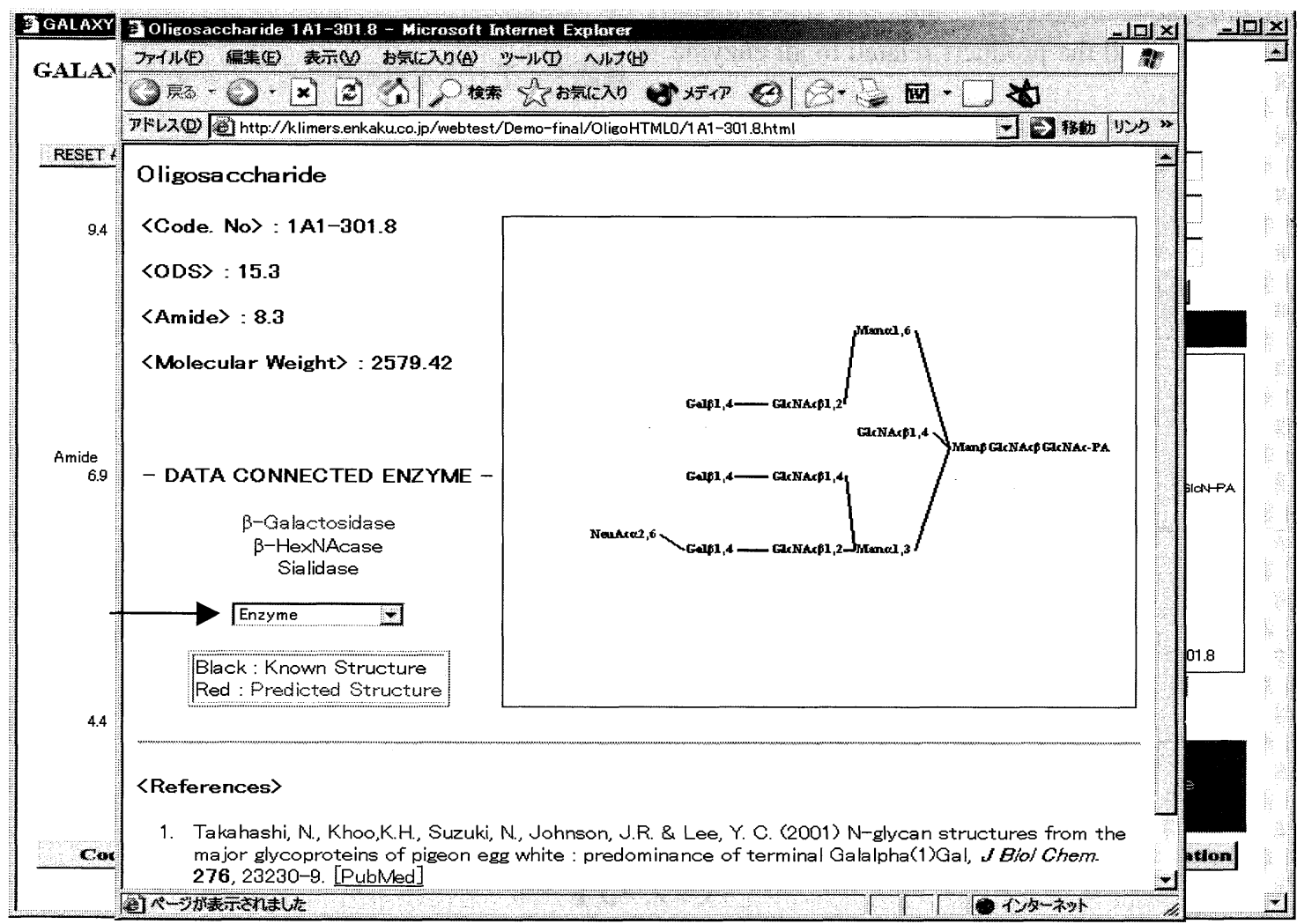

Fig.18. Information page. 


\section{B-10. Information Page}

The link related to the particular product is as shown in Fig. 18. This link is called "Information page". This page contains detailed information about the selected product.

ODS, Amide, MW values are displayed along with product code number. It also provides information about the data connected enzyme.

Under the 'DATA CONNECTED ENZYME' heading data connected enzyme list is displayed. The user can select the displayed enzyme from the choice box. The connected structure is displayed according to the selected enzyme.

Unknown data and enzymes are displayed in RED. In this case it is mentioned at the top of the HTML page.

Known products and enzymes are displayed in Black.

\section{Customer Support:}

In case of System assistance please contact us on +81-64792-6088 or Fax at 06-4792-6089.

E - mail us at info@primmune.com

For bug reports please mail at info@primmune.com

If you need more information about this product, download user manual or contact SystemInfo.

\section{Acknowledgement}

We are greatly indebted to Primmune K.K. and to KLIMERS for their generous support. This work was supported by a Grant-in-Aid from the Ministry of Education, Culture, Sports, Science and Technology of Japan, and a grant from CREST, JST.
B-10. 詳細ページ

ダブルクリックもしくは HTML Link ボタンをクリックす ると、図18 のような新たなブラウザが開き、詳細ページが表示 されます。

図 18 の矢印のチョイスボックスを変更すると、表示されて いる糖鎖を選択した消化酵素によって処理した構造にリンクす ることが可能です。

"DATA CONNECTED ENZYME"とチョイスボックスの間 に表示されている消化酵素はその構造を消化可能な酵素を示し ます。この部分に表示されていない消化酵素を選択しても、リ ンクされません。

この部分に何の記述もされていない場合は、どの消化䤃素

を用いても消化できないことを表します。

表示文字色

黑: 消化後の構造が既知糖鎖である。

赤：消化後の構造が未知糖鎖である。(リンク後、次の消化 処理が不可能)

C. サポート情報

糖鎖解析部門

株式会社プライミューン 厂540-0026 大阪市中央区内本町 1-2-5 YSK ビル 6 階 電話：06-4792-6088

FAX :06-4792-6089

E-mail : info@primmune.com

URL : http://www.primmune.com/

謝 辞

本稿を作成するにあたり、ご尽力頂いた株式会社プライ ミューンおよび株式会社 遠隔医療研究所バイオインフォマ ティクス研究室の皆様に感謝致します。本アプリケーションの 開発は、文部科学省・科学研究費 (特定領域研究) および科学技 術振興事業団・戦略的創造研究推進事業の支援によって行われ ました。 